Check for updates

Stockholm

Cite this as: BMJ 2021;375:n2575 http://dx.doi.org/10.1136/bmi.n2575 Published: 20 October 2021

\title{
Covid-19: Italy sees protests against mandatory health passports for workplaces
}

Marta Paterlini

A demonstration in Trieste, Italy, against the mandate for health passports in the workplace turned into a riot on 18 October, with police using tear gas and water cannons to disperse crowds.

Protests against the use of covid passports have been spreading throughout the country, with protestors claiming they are discriminatory.

This autumn the Italian government approved ${ }^{1}$ some of the strictest anti-covid-19 measures in the world, including making it mandatory for all workers to have a so-called green pass before returning to workplaces. The green pass provides proof that someone has either been vaccinated, recently recovered from covid, or has had a negative rapid swab test for the virus. A worker without a green pass must take unpaid leave and may be fined between $€ 400$ and $€ 1500$.

Italy made vaccination mandatory for healthcare workers ${ }^{2}$ in April this year. In July the green pass was introduced as a requirement to enter any indoor venue or event, and was extended to schools, universities, trains, and aeroplanes in September.

Italy was the first European country to be hit by covid-19 and the first to enter lockdown in March 2020. ${ }^{3}$ It was among the most affected countries in the first outbreak and in following waves, and has one of the highest fatality rates ${ }^{4}$ worldwide, with mortality particularly high among patients aged 70 years or older.

Now, more than $81.5 \%$ of people in Italy over the age of 12 are fully vaccinated ${ }^{5}$ against covid-19 (the target is to reach $90 \%$ by December) and the spread is slowing, with 2695 new cases and 70 deaths registered on 19 October.

While the national mandate has stirred protests among those who feel that Prime Minister Mario Draghi's decision contravenes the Italian constitution, many experts think this is the only way to fight the pandemic.

Laura Palazzani, deputy vice president of the National Bioethics Committee, said the green pass ${ }^{6}$ enabled a relaxation from lockdown policies while containing covid to normalise social and economic activities. The constitutional basis is the protection of health both on individual and collective basis. It should be a temporary measure to be reduced and stopped when herd immunity is reached.

Maurizio Cecconi, intensivist at Humanitas Research Hospital in Milan and president of the European Society of Intensive Care Medicine, told The BMJ, "Keeping in mind that the situation is dynamic, as we learnt in the past 18 months, Italy is doing fairly well epidemiologically as well as at the clinical level."
Cecconi, who was the first doctor ${ }^{7}$ to warn European colleagues about the novel coronavirus in China, said that Italian intensive care units are now mainly occupied by unvaccinated people and by vaccinated but frail elderly patients. "The government's strategy makes sense because, with the help of the green pass and the mandatory wearing of masks indoors, we are going towards an endemic situation," he said.

Ilaria Capua, a virologist and director of the One Health Center of Excellence at the University of Florida in the US, told The BMJ that Italy had made a great comeback after being "heavily affected." She said there was a psychological toll after the country was "initially left alone" after becoming one of the first in the West to see soaring infections.

Capua argued that Italy's vaccination campaign was going well, and that the green pass was a measure of persuasion for the sake of public health. "The government must push public health to protect the majority," she said.

1 Leggi ed altri atti normativi. www.anci.it/wp-content/uploads/d.l.-21.9.21n.-127-green-pass.pdf.

2 Paterlini M. Covid-19: Italy makes vaccination mandatory for healthcare workers. BMJ2021;373:n905. doi: 10.1136/bmj.n905 pmid: 33824155

3 Paterlini M. Covid:19: Italy has wasted the sacrifices of the first wave, say experts. BMJ2020;371:m4279. doi: 10.1136/bmj.m4279 pmid: 33184040

4 Case fatality rates of covid-19 in select countries worldwide from February 25 to August 17, 2020. www.statista.com/statistics/1076314/covid-19case-fatality-rates-select-countries-worldwide.

5 Coronavirus vaccinations. https://ourworldindata.org/covid-vaccinations?country=OWID_WRL.

6 Vaccine passport, Certificate and Green pass, within the Covid-19 pandemic: bioethical aspects. 30 April 2021. https://bioetica.governo.it/en/opinions/opinions-responses/vaccine-passport-certificate-and-green-passwithin-the-covid-19-pandemic-bioethical-aspects.

7 Paterlini M. Covid-19: Maurizio Cecconi-one year since Italy's darkest moment. BMJ 2021;372

This article is made freely available for use in accordance with BMJ's website terms and conditions for the duration of the covid-19 pandemic or until otherwise determined by BMJ. You may use, download and print the article for any lawful, non-commercial purpose (including text and data mining) provided that all copyright notices and trade marks are retained. 